Central European Review of Economics \& Finance

Vol. 23, No. 1 (2018), pp. 69-85

DOI: $10.24136 /$ ceref.2018.006

Received: 19 December 2017. Accepted: 23 January 2018

Małgorzata CZERMIŃSKA ${ }^{1}$, Joanna GARLIŃSKA-BIELAWSKA²

\title{
THE PROS AND CONS OF THE ECONOMIC PARTNERSHIP AGREEMENT (EPA) FOR THE SOUTHERN AFRICAN DEVELOPMENT COMMUNITY (SADC) IN THE CONTEXT OF MEMBER STATES' TRADE RELATIONS WITH THE EUROPEAN UNION (EU)
}

The article aims to present the benefits and costs for the SADC member countries of the conclusion of EPA and of the implementation of trade liberalisation thereunder, in the light of their trade relations with the European Union. The hypothesis adopted is that for the majority of the SADC countries entering into the agreement will involve improved access for their products to the EU market. The assessment of the advantages and disadvantages of the conclusion of an EPA will take account of a situation in which the countries of the region would not sign an EPA: how their customs status would change and whether it would affect the conditions of trade with the European Union.

JEL Classification Codes: F13, F14, F15.

Keywords: Economic Partnership Agreement (EPA), Southern Africa, Southern African Development Community (SADC), international trade.

\footnotetext{
${ }^{1}$ Assistant professor, PhD, Andrzej Frycz Modrzewski Krakow University.

${ }^{2}$ Adjunct lecturer, PhD, Cracow University of Economics.

${ }^{3}$ The publication was co-financed from funds allocated to the statutory activity of the Faculty of Law, Administration and International Relations at the Andrzej Frycz Modrzewski Krakow University no. WPAiSM/DS/8/2017 and as a subsidy for maintaining the research capacity of the Faculty of Economics and International Relations at the Cracow University of Economics.
} 


\section{Introduction}

The relations between the European Union (EU) and the African Caribbean and Pacific states (ACP) date back to the Treaty of Rome, containing provisions concerning mutual cooperation. The Cotonou Agreement, signed in 2000 and concluded for a term of 20 years, marked a new stage in the development of mutual trade relations. An important element of the Agreement was to negotiate Economic Partnership Agreements (EPAs) during a specified period. Those were supposed to be agreements providing for a progressive removal of barriers to trade on a mutual basis, including the liberalisation of essentially all trade in goods, as well as for reducing obstacles in other trade-related areas, e.g. trade in services. Basically, EPAs were intended to support regional integration between the ACP States, to promote their development and to contribute to poverty eradication in the countries concerned. Negotiations on EPAs are conducted in several regional areas, including Southern Africa.

The group of countries functioning in the region, referred to as the Southern African Development Community (SADC), comprises fifteen countries but only half of the member states are engaged in the SADC EPA negotiations (Angola as an observer, Botswana, Lesotho, Mozambique, Namibia, South Africa and Swaziland). The very fact indicates a certain disparity between the goals set by the European Union and their actual implementation, particularly towards promoting regional economic integration in Africa ${ }^{4}$.

The article aims to present the benefits and costs for the SADC member countries of the conclusion of EPA and of the implementation of trade liberalisation thereunder, in the light of their trade relations with the European Union. The hypothesis adopted is that for the majority of the SADC countries entering into the agreement will involve improved access for their products to the EU market. The assessment of the advantages and disadvantages of the conclusion of an EPA will take account of a situation in which the countries of the region would not sign an EPA: how their customs status would change and whether it would affect the conditions of trade with the European Union.

The article employed an analytical and descriptive method based on sources from the national and international literature, secondary legislation of the EU in the form of regulations as well as on EUROSTAT statistics.

\section{Southern Africa}

Southern Africa is a relatively well-developed region on the African continent. This position is earned by the Republic of South Africa (the RSA or South Africa), the most important economy in the region and simultaneously the second largest African econo-

\footnotetext{
${ }^{4}$ Both the Cotonou Agreement and the SADC EPA refer to promoting, supporting and strengthening regional integration. See: The Cotonou Agreement (Section 3) and the SADC EPAArticle 1 (b) and Article 3.
} 
my behind Nigeria (for more see: Rynarzewski, Nawrot, Zajączowski \& Cieślik, 2017, pp. 133-152). Apart from South Africa, the region, accounting for one-third of the area of the continent, includes fourteen more countries, very differentiated but, as a whole, in 2015 they achieved an average GDP growth rate (3.2\%) significantly above the African average $(2.2 \%)$. As a result, in that part of Africa average GDP per capita (USD 3,549) is nearly double the figure for the whole continent (USD 1,958) [Table 1].

Table 1. Area, population and GDP of the SADC-EPA Group countries with Angola, the SADC and Africa in 2015

\begin{tabular}{|l|r|r|r|r|r|}
\hline & Area $\left(\mathbf{k m}^{2}\right)$ & $\begin{array}{c}\text { Population } \\
\text { (thousand persons) }\end{array}$ & $\begin{array}{c}\text { GDP } \\
\text { (USD million) }\end{array}$ & $\begin{array}{c}\text { GDP } \\
\text { per capita (USD) }\end{array}$ & $\begin{array}{c}\text { GDP } \\
\text { growth rate (\%) }\end{array}$ \\
\hline Angola & 1246700 & 25022 & 115143 & 4602 & 0.9 \\
\hline Botswana & 581750 & 2200 & 14410 & 6369 & -1.7 \\
\hline Lesotho & 30360 & 2200 & 2049 & 960 & 1.6 \\
\hline Mozambique & 799380 & 26400 & 14798 & 529 & 6.6 \\
\hline Namibia & 284290 & 2459 & 11559 & 4701 & 5.3 \\
\hline South Africa & 1219090 & 55654 & 316139 & 5802 & 1.3 \\
\hline Swaziland & 17360 & 1300 & 3927 & 3052 & 1.1 \\
\hline SADC-EPA & 4161570 & 115235 & 478070 & 4336 & 2.2 \\
\hline DR Congo & 2344860 & 77266 & 37587 & 486 & 7.7 \\
\hline Madagascar & 587295 & 23650 & 9703 & 400 & 3.1 \\
\hline Malawi & 118480 & 16832 & 6430 & 374 & 2.9 \\
\hline Mauritius & 2040 & 1264 & 11683 & 9175 & 3.5 \\
\hline Seychelles & 460 & 97 & 1377 & 14276 & 5.0 \\
\hline Tanzania & 947303 & 53470 & 45628 & 853 & 7.0 \\
\hline Zambia & 752510 & 16212 & 21243 & 1310 & 2.9 \\
\hline Zimbabwe & 390757 & 14240 & 5229 & 335 & 1.4 \\
\hline SADC & 9305275 & 318266 & 616950 & 3549 & 3.2 \\
\hline AFRICA & 30370000 & 1184501 & 2273552 & 1958 & 2.2 \\
\hline
\end{tabular}

Source: own study based on: (African Statistical Yearbook 2017).

In the literature, there are two conflicting views on the role of South Africa in SubSaharan Africa. On the one hand, the economic power of South Africa is treated as a potential threat to regional integration; on the other hand, it is seen as an opportunity for regional development (for more see: Borgatti, 2011, pp. 471-481). Undoubtedly, South Africa is instrumental in both communities functioning in that part of the continent, i.e. the Southern African Customs Union (SACU) and the Southern African Development Community (SADC).

The SACU is the world's longest-lasting customs union, with colonial roots and dating back to 1889. In addition to South Africa, it comprises Botswana, Lesotho, Swaziland and Namibia (referred to as BLSN). Apart from a common external tariff, the mem- 
ber states also have a common excise tariff (for more see: McCarty 2003, pp. 1-36; Michałowski 2011, pp. 186-197); furthermore, the member states (with the exception of Botswana) belong to the Common Monetary Area, originating from the Southern African Rand Monetary Area (for more see: Młodkowski, 2007, pp. 172-227).

The other group in the region is the Southern African Development Community, established in 1992 from the Southern African Development Coordination Conference (SADCC) functioning until 1980. The reasons for the formation of the SADCC were purely political and focussed on strengthening regional cooperation between the then member countries (Angola, Botswana, Mozambique, Tanzania, Zambia, Zimbabwe, Lesotho, Malawi, Swaziland and, from 1990, Namibia) in order to reduce economic dependence on South Africa. At that time, a proposal for establishing a customs union was rejected and emphasis was placed on sectoral integration, including in particular the development of transport and communication, followed by the energy sector, industry and agriculture (Foroutan, 1993, pp. 241-242). The end of the apartheid era, the transformation of the SADCC into the SADC and the resulting accession of South Africa led to the formation of a bloc playing the dominant role, both politically (due to the position of South Africa) and economically (the highest combined GDP on the continent) (Dinka \& Kennes, 2007, p. 8).

In the 2010s, in addition to the above-mentioned countries, the SADC also includes Mauritius (from 1995), the Democratic Republic of the Congo and Seychelles (from 1997) as well as Madagascar (from 2005). The community has become a free trade area but the process of building a customs union, initially planned to be in place as early as $\mathbf{2 0 1 0}$, is considerably delayed. The situation is caused by various and complex factors such as the multiple memberships of the member countries of the community, including of customs unions. All the SACU countries are simultaneously members of the SADC, thus forming a sub-community of the former. In addition, Tanzania belongs to the East African Community (EAC), whereas the Democratic Republic of the Congo, Seychelles, Swaziland, Zambia and Zimbabwe are members of the Common Market for Eastern and Southern Africa (COMESA). The EAC and the COMESA are both customs unions and, from 2015, they are also (with the SADC) members of an additional agreement establishing a free trade area: the Tripartite Free Trade Area, TFTA (for more see: Garlińska-Bielawska, 2016, pp. 63-70). 


\section{The origin and the state of play of the negotiations concerning the SADC Economic Partnership Agreement (SADC EPA)}

In terms of their trade regimes in relations with the European Union, the SADC countries rank among the African, Caribbean and Pacific Group of States (ACP) $)^{5}$. The group is formed by former colonies of some of the EU Member States, having special trade relations with the EU from its inception. From 1975, they enjoyed duty-free access to the EU market for all industrial and agricultural goods, with the exception of temperate zone products posing competition to EU products and covered by the common agricultural policy ${ }^{6}$. Those were non-mutual preferences so the countries of the region were not obliged to grant the same concessions to EU goods. But such unilateral trade preferences were inconsistent with the WTO rules, therefore they needed to be replaced with mutual preferences in the form of creating free trade areas, including between the EU and Southern Africa. However, the establishment of free trade areas involves the lifting of tariffs in mutual trade, in this case by Southern African countries (the EU eliminated most tariffs much earlier).

A new stage in the development of mutual relations with the SADC countries (and with all the ACP States in general) was marked by the Partnership Agreement signed in Cotonou on 23 June 2003 for a period of twenty years (from March 2000 to February 2020), with a possible review every five years (which took place in 2005 and 2010). The Cotonou Partnership Agreement was the EU's largest international agreement governing relations between the 28 European Union Member States and the 78 ACP States ${ }^{7}$. The Cotonou Agreement was designed to establish a comprehensive partnership with 3 pillars: development cooperation, political cooperation and economic and trade cooperation (for the period 2000-2007) (Partnership agreement between the members of the African, Caribbean and Pacific Group of States of the one part, and the European Community and its Member States, of the other part, signed in Cotonou on 23 June

\footnotetext{
${ }^{5}$ A group of countries created under the Georgetown Agreement of 6 June 1975, currently including 79 states. A detailed list of the states can be found at the website of the African, Caribbean, and Pacific Group of States, http://www.acp.int/content/secretariat-acp

${ }^{6}$ Those were unilateral preferences granted under the Convention of Lomé (in 1975-2000) and intended, inter alia, to increase mutual trade. On 28 November 1979, the Contracting Parties to GATT decided to adopt an enabling clause as a permanent derogation to the MFN treatment in order to allow developed countries to accord preferential tariff treatment to developing countries in accordance with the Generalised system of Preferences (GSP). Such preferences must be granted on a non-discriminatory basis to countries benefiting from non-reciprocal preferences. However, the preferences accorded to the ACP States were discriminatory in nature as they were more favourable than those granted to other developing countries under the GSP. Therefore, until the end of 2007 the European Union had a WTO waiver (a derogation from the fundamental principles) for preferential trade with the ACP States.

${ }^{7}$ Among the ACP states, Cuba was the only country not to sign the agreement. Therefore, the Cotonou Agreement covers as many as 108 countries from four continents.
} 
2000). Within the third pillar, negotiations concerning regional economic partnership agreements (EPAs) were to be initiated in 2002-2007, one of the regions being Southern Africa. Those were supposed to be new trade agreements, consistent with the WTO principles regarding regional free trade areas and aimed to gradually eliminate, on a reciprocal basis, barriers to trade between the parties and to extend cooperation to include all trade-related fields, in particular services and investment, copyright and the environmental protection, border controls and customs procedures ${ }^{8}$. There are three conditions for introducing new rules of trade relations between the ACP States and the European Union. The first condition is legal in nature as it concerns the aforementioned compliance with the WTO principles. Secondly, it is economically necessary to reform the inefficient system of mutual trade relations based on the Conventions of Lomé (Koné, 2010, p. 106). Trade governed by the above-mentioned rules did not bring the expected results as the share of ACP exports to the EU in the EU market dropped considerably, from 6.7\% in 1976 to 2.8\% in 1994 (European Commission 1996). Tariff preferences and financial aid failed to counteract the marginalisation of the ACP States in world trade, neither did they contribute to the diversification of exports of the countries in question. The ineffective functioning of trade facilities for the ACP States was further undermined by the liberalisation of trade within the GATT/WTO, which gradually reduced trade between the EU and the group of countries concerned (Frankowski, 2011, p. 33). The third reason is political in nature as it is related to maintaining the European Union's strong position in the region as the main exporter and importer as well as benefactor, which was particularly important in the context of expanding activities of China in Africa.

In the case of trade in goods, EPAs were supposed to lead to the liberalisation of basically all trade between the parties, which according to the EU interpretation accounted for ca. $90 \%$ of mutual trade. On the part of the EU, asymmetrical liberalisation covers almost $100 \%$ of mutual trade, whereas on the part of the ACP States the respective share is $80 \%$, which results in the liberalisation of around $90 \%$ of mutual trade in goods. The aforementioned agreements were also intended to foster regional integration and to promote a gradual inclusion of the ACP States in the world economy.

The opening session allowed to arrive at an agreement to sequence the negotiations in two phases. The first phase took place at an all-ACP-EU level and addressed horizontal issues of interest to all parties. The second ACP-EC ministerial meeting was held in October 2003 and marked the beginning of the second phase of the negotiations. Stage 2 included the actual negotiations and developing specific commitments at the level of individual regions to negotiate particular agreements, pursuant to Article 37 of the Cotonou Agreement (Partnership agreement between the members of the African, Caribbean and Pacific Group of States of the one part, and the European Com-

\footnotetext{
${ }^{8}$ All the SADC EPA countries are WTO members.
} 
munity and its Member States, of the other part, signed in Cotonou on 23 June 2000, pp. 3-353). In December 2004, six regions started formal negotiations: West Africa, Central Africa, Eastern and Southern Africa, Caribbean, SADC (Southern Africa), Pacific $^{9}$. Therefore, one of those regions represented the SADC countries.

Initially, seven member states from the Southern African Development Community (SADC) began negotiations: Botswana, Lesotho, Namibia, Swaziland, Mozambique, Angola and Tanzania. Four of the above-mentioned countries - Lesotho, Mozambique, Angola and Tanzania - were classified as the least developed countries (LDCs). The Republic of South Africa also participated in those negotiations but as an observer only ${ }^{10}$. Botswana was designated to coordinate the overall efforts in the configuration of the SADC EPA and to prepare negotiating positions, whereas each member state of the SADC EPA was assigned a negotiation area or issues to coordinate (e.g.: Angola Agriculture, Angola and Mozambique - Non-Agricultural Market Access) $)^{11}$. The process of negotiating the SADC-EU EPA was particularly complicated for three reasons: firstly, in 1999 South Africa had signed the Trade, Development and Cooperation Agreement (TDCA) with the European Union and insisted on a treatment different from that granted

\footnotetext{
${ }^{9}$ At a later time, negotiations also started with another (the seventh) region, i.e. the East African Community (EAC).

${ }^{10}$ The SADC countries formed a separate negotiating group in 2007; at that time, South Africa joined the negotiations as well. Owing to its relatively limited role in the SADC group negotiations, for a time Tanzania continued them in the group of the East Africa Community (EAC), of which it is also a member state. Therefore, the SADC EPA group includes seven countries: Botswana, Lesotho, Namibia, Swaziland (BLNS), South Africa, Mozambique and Angola, as an observer.

${ }^{11}$ For more on the subject see: (McCarthy, Kruger, \& Fourie, 2007, p. 4).
} 
to the other countries of the sub-region ${ }^{12}$; secondly, the existence of regional agreements such as the SADC but also the Southern African Customs Union (SACU); and thirdly, only 6 SADC countries ${ }^{13}$ negotiated the EPA as a whole (five of them belong to another regional community, i.e. the SACU - BLNS and South Africa). Therefore, the discussion below only refers to the SADC EPA Group rather than to all the community members.

Under the Cotonou Agreement, EPAs with Southern African countries were supposed to be negotiated by 31 December 2007 and to include the creation of free trade areas with reciprocal trade preferences. The relevant provisions of the Cotonou Agreement, providing for unilateral trade preferences for the ACP states, expired on 31 December 2007. Due to the limited progress in EPA negotiations with the ACP States, including with Southern African countries, the European Union threatened to withdraw the preferences, thus with a loss of preferential access to the common market (for countries other than LDCs). With the aim of bridging the gap for the countries which had been yet unable to negotiate EPAs (which also applied to Southern African countries), the EU introduced transitional solutions to be effective from 1 January 2008, laid down in Council Regulation (EC) No 1528/2007, the so-called Market Access Regulation (MAR).

\footnotetext{
${ }^{12}$ After the end of the apartheid era and the democratic revolution in 1994, the South African government applied for membership of the ACP Group of States, also with a view to benefiting from trade preferences granted by the EU to the group of countries concerned under the Convention of Lomé then in force. However, the EU refused to grant unilateral Lomé preferences to South Africa; entering into a mutual free trade agreement was proposed instead. The main reason was that many South African products, especially in the agricultural sector, were internationally competitive, therefore the southern European Member States feared the replacement of certain domestic products by cheaper goods imported from South Africa. In turn, South Africa was reluctant to conclude a free trade agreement with the EU as it was concerned that its industrial products would be squeezed out by more competitive imports from the EU; moreover, the EU subsidised its agricultural products exported to South Africa, which increased their competitiveness (Meyn, 2003, p. 3). Following five years of negotiations, on 11 October 1999 both parties signed the agreement, provisionally entering into force on 1 January 2000 but it was only ratified in April 2004. It provided for the creation of a free trade area after the transitional period lasting until 2012. South Africa eliminated tariffs on $86 \%$ of goods imported from the EU, whereas the European Union - 96\%. Until 2010, South Africa enjoyed duty-free access for $99.98 \%$ of its industrial exports, with a mere $0.02 \%$ of products subject to tariffs (mostly aluminium) (Meyn, 2003, p. 3). South Africa belongs to the SACU, also including much smaller countries such as: Botswana, Lesotho, Namibia and Swaziland (BLNS). Those countries did not participate in the negotiations although they were directly affected by the TDCA. The reason was that duty-free imports to South Africa could be afterwards exported without tariffs to the other SACU countries and, due to their price competitiveness, squeeze out local suppliers. The situation was further aggravated by declining receipts from customs duties in the countries for which customs receipts represented a significant source of budget revenue: for Swaziland and Lesotho (a landlocked country receiving goods imported to South Africa and then re-exported, on a duty-free basis, to Lesotho) - ca. $60 \%$, for Botswana and Namibia - between $20 \%$ and $40 \%$. Neither did the TDCA meet the expectations of South Africa. Over more than a dozen years, the share of South African exporters in the EU market dropped from $1.45 \%$ (2003) to $1.3 \%$ (2016).

${ }^{13}$ The seventh country - Angola - did not sign the agreement but it had participated in the negotiations and may join the agreement at any time in the future.
} 
(Council Regulation (EC) No 1528/2007 of 20 December 2007 applying the arrangements for products originating in certain states which are part of the African, Caribbean and Pacific (ACP) Group of States provided for in agreements establishing, or leading to the establishment of, Economic Partnership Agreements). The Regulation laid down the EU import arrangements for products originating in the ACP states which negotiated EPAs but had not signed and ratified them by the end of $2007^{14}$. It concerned the SADC EPA Group as well. The European Union unilaterally granted to those countries preferential market access (duty-free access offered by the EU under such agreements, pending their entry into force). Where a country failed to meet the criteria of the Regulation, the preferences should be withdrawn and the trade arrangement resulting from the country's customs status should be applied (Everything but Arms, the Standard GSP or GSP Plus, MFN treatment) (For more on the GSP see, inter alia: Czermińska, 2017, pp. 41-58; Czermińska, 2016, pp. 43-51). The effective date of that amendment was 1 October 2014. It would mean for two countries of the region: Namibia and Botswana (as middle-income countries) the lack of tariff preferences, thus deteriorated conditions of access to the EU market, as they would no longer qualify under the GSP. The ensuing losses are estimated at EUR 29 million and EUR 58 million respectively (South Centre, 2012, p. 14). At the same time, Swaziland would remain a beneficiary of the GSP, whereas Lesotho, Mozambique and Angola would still benefit from EBA as LDCs ${ }^{15}$. However, Swaziland's main export products in trade with the EU, e.g. raw cane sugar for refining, cane sugar and its prepared and preserved fruits, are excluded from the GSP, therefore the country's losses caused by the loss of preferences are estimated at approx. EUR 65 million (South Centre, 2013, p. 14). South Africa would no longer qualify as a beneficiary of the reformed GSP but it would trade with the EU under the TDCA.

However, since several years later a significant number of the ACP states neither took the necessary steps to ratify economic partnership agreements nor concluded comprehensive regional negotiations, the MAR was amended in May 2013. (Regulation (EU) No 527/2013 of the European Parliament and of the Council of 21 May 2013 amending Council Regulation (EC) No 1528/2007). Preferential access to the EU market was maintained only for those countries which had ratified EPAs or concluded negotiations concerning regional economic partnership agreements before 1 October 2014. Among the many ACP states, merely 19 countries were included in that list. Neither were the criteria for maintaining preferences satisfied by BLSMN (Annex I to the Regulation).

\footnotetext{
${ }^{14}$ The countries are listed in Annex I to the MAR.

${ }^{15}$ The system was introduced for LDCs into the GSP in 2001 under Council Regulation (EC) No 416/2001. The system of preferences for LDCs ensured duty-free access to the EU market, with no quantity limitations, for all goods, except for Chapter 93 of the Combined Nomenclature, i.e. arms and ammunition $199.8 \%$ of all tariff lines). Those preferences were granted for an unlimited time period and, moreover, they did not need to be reviewed periodically, which was the case with the GSP (Everything but Arms Arrangement).
} 
Only Botswana, Mozambique, Lesotho and Swaziland undertook to also negotiate other issues such as services and investment, whereas South Africa agreed to address issues related to Geographical Indications (GI) (South Centre, 2013, p. 14).

Finally, negotiations on economic partnership agreements (EPAs) between the EU and the SADC (Southern African Development Community) EPA group were concluded on 15 July 2014, after more than 10 years of negotiations. The agreement was signed by the EU and the SADC EPA group on 10 June 2016 and the European Parliament gave its consent on 14 September 2016. Pending ratification by all the EU Member States, the agreement provisionally entered into force as of 10 October 2016. Mozambique is in the process of submitting the ratification instrument to the Council, after which the agreement will enter provisionally into force also for that country (European Commission, Trade, The ACP regions, Overview of Economic Partnership Agreements, Updated November 2017).

\section{The main provisions of the SADC EPA concerning trade in goods}

The core of the EPA contains the provisions on trade in goods. Those are mutual preferences consisting in the elimination of or partial reduction in import tariffs. Under the SADC EPA, the EU grants its partners duty-free and quota-free access for nearly all goods (with the exception of Chapter 93 of the Harmonised System) for Botswana, Lesotho, Mozambique, Namibia and Swaziland (BLMNS) [Table 2]. The SADC EPA countries are provided with an asymmetric and gradual opening of their markets to EU goods, taking full account of the differences in levels of development between them and the EU. Botswana, Lesotho, Mozambique, Namibia and Swaziland decided to liberalise mainly industrial and fisheries products. BLMNS excluded from liberalisation mostly goods in the agricultural, textile and processed agricultural product sectors.

Whereas the EPA objective is to continue and ensure duty-free access to the EU market, enjoyed by BLMNS for decades, in the case of South Africa the agreement is aimed at improving the market access conditions laid down in the TDCA. The agreement in question granted to South Africa significantly liberalised access to the EU market, the EPA introduced additional selective and partial liberalisation. Selective as it applies to selected agricultural products; partial as it means the establishment of Tariff-Rate Quotas (TRQs) ${ }^{16}$. It concerns South Africa's major export products, e.g. sugar, wine, fruit and fruit juices. New market access for South Africa into the EU means that the fish sector will be fully liberalised and South Africa will benefit from TRQs on selected tariff lines of wine, sugar, fruit juices, citrus jams, canned fruit, skimmed milk powder, butter,

\footnotetext{
${ }^{16}$ Those concern specified quantities of products subject to lower tariffs in the quota period.
} 
yeast and ethano ${ }^{17}$. Combined with full and partial liberalisation, the SADC Economic Partnership Agreement will lead to a liberalisation of $98.7 \%$ of actual exports from South Africa to the EU (European Commission, 2016 b, p. 16); [Table 2].

Table 2. Scope of tariff elimination and reduction provided by the SADC EPA

\begin{tabular}{|l|c|c|}
\hline & Tariff lines & $\begin{array}{c}\text { Share of actual trade in volume } \\
(2012-2014)\end{array}$ \\
\hline \multicolumn{3}{|c|}{ EU offer to BLMNS } \\
\hline Full liberalisation & $\begin{array}{l}100 \% \text { (except arms and ammunition, } \\
\text { HS Chapter 93) }\end{array}$ & $\begin{array}{l}100 \% \text { (except arms and ammunition, } \\
\text { HS Chapter 93) }\end{array}$ \\
\hline \multicolumn{3}{|c|}{ EU offer to South Africa } \\
\hline Full liberalisation & $94.9 \%$ & $96.0 \%$ \\
\hline Partial liberalisation & $3.2 \%$ & $2.7 \%$ \\
\hline Excluded & $1.9 \%$ & $1.3 \%$ \\
\hline \multicolumn{3}{|c|}{ SACU offer to EU } \\
\hline Full liberalisation & $84.9 \%$ & $74.1 \%$ \\
\hline Partial liberalisation & $12.9 \%$ & $12.1 \%$ \\
\hline Excluded & $2.2 \%$ & $13.8 \%$ \\
\hline \multicolumn{3}{|c|}{ Mozambique offer to EU } \\
\hline Full liberalisation & $81.0 \%$ & $76.0 \%$ \\
\hline Excluded & $19.0 \%$ & $24.0 \%$ \\
\hline
\end{tabular}

Source: (European Commission 2016a; European Commission 2016b).

Another novelty in the EPA SA (South Africa) is the protection of traditional product names. It concerns the so-called geographical indications (Gls); more than $250 \mathrm{Gls}$ from the EU and over 100 South African Gls will be protected (e.g. herbal teas popular in South Africa: Rooibos, Honeybush, Karoo Lamb, a number of wine names as well). For example, a producer in a country other than South Africa cannot market a tea processed from a plant from its own territory under the symbolically important name Rooibos. The same applies to EU traditional product names (European Commission 2016 a). Therefore, almost all South African products (ca. 99\%) have preferential market access in the EU, compared to about $95 \%$ under the previous agreement. Approx. $96 \%$ of the products can enter the EU market without being subjected to customs duties or quantitative restrictions. The other $3 \%$ still have access, although partial, that is similar or improved in comparison with the TDCA. The SACU as a group has granted the EU lower market access of $86 \%$, in line with the developmental nature of the agreement

\footnotetext{
${ }^{17}$ For example: South Africa is now allowed to export 150,000 tonnes of sugar and 80,000 tonnes of ethanol duty free, whereas the quota for wine exports to the EU has more than doubled, from 50 million to 110 million litres.
} 
[Table 2]. The provisions also contain a chapter on trade defence with bilateral safeguards allowing each of the parties to reintroduce duties or quotas where imports from the other party disturb or threaten to disturb their economy. However, South Africa was mostly concerned about restricting the freedom of entering into trade agreements with 'major trading economies', i.e. countries accounting for a share of world merchandise exports above $1 \%$ in the year before the entry into force of the agreement, or any group of countries acting individually, collectively or through an economic integration agreement accounting collectively for a share of world merchandise exports above $1.5 \%$ in the year before the entry into force of the agreement (Article 28 of the SADC EPA). In practice, South Africa has limited possibilities to conclude trade agreements with Brazil, Russia, China or India.

\section{The role of economic partnership agreements in trade relations between Southern African countries and the European Union}

An analysis of the costs and benefits of entering into the SADC Economic Partnership Agreement directly entails answering the question what would happen if the Southern African countries had not concluded EPAs. In the case of Botswana and Namibia, upper middle-income countries, exports to the EU would be subject to the MFN tariffs, applied to all WTO members. It would mean deteriorated conditions of access to the EU market, e.g. for beef exports, since the MFN tariff is relatively high. Swaziland, a lower middleincome company, without an EPA would be covered by the GSP. The system offers a number of tariff preferences but excludes sugar, a major export product of Swaziland. Lesotho and Mozambique, the two least developed countries (LDCs) in the region, would still benefit from the EBA arrangement, thus their EU market access conditions would not worsen. Finally, trade with South Africa would continue to be regulated by the Trade, Development and Cooperation Agreement (TDCA) [Table 3].

Table 3. SADC EPA Group and their current and ' $\rightarrow$ ' future market access arrangement if no EPAs are ratified

\begin{tabular}{|c|c|}
\hline Country & Customs status/market access \\
\hline \multicolumn{2}{|l|}{ The same access conditions } \\
\hline Lesotho (LDC), Mozambique (LDC), South Africa (TDCA), Angola (LDC) & No change \\
\hline \multicolumn{2}{|l|}{ Deteriorated access conditions } \\
\hline Swaziland & $\mathrm{MAR} \rightarrow \mathrm{GSP}$ \\
\hline Botswana, Namibia & $M A R \rightarrow$ MFN \\
\hline
\end{tabular}

Source: own study based on: (Council Regulation (EC) No 1528/2007 of 20 December 2007; Commission Delegated Regulation (EU) No 1016/2014 of 22 July 2014). 
In terms of general benefits and costs of the conclusion of EPAs by Southern African countries, the benefits would include duty-free access to the EU market, whereas the costs would be the necessity to open up their own markets by lifting tariffs and exposure to competition from EU producers and, in the future, service providers as well, lower flexibility in increasing tariffs should such a need arise in the future; in addition, a fall in revenue from customs duties.

Table 4. EU trade with the SADC EPA group of countries and with Angola in 2013-2016 (EUR million)

\begin{tabular}{|c|c|c|c|c|c|c|c|c|}
\hline \multirow[b]{3}{*}{ ngala } & \multicolumn{4}{|c|}{ IMPORTS } & \multicolumn{4}{|c|}{ EXPORTS } \\
\hline & 2013 & 2014 & 2015 & 2016 & 2013 & 2014 & 2015 & 2016 \\
\hline & 9,308 & 9,389 & 7,981 & 4,188 & 6,197 & 6,741 & 4,856 & 3,388 \\
\hline $\begin{array}{l}\text { main commodities } \\
\text { as (\%) of total }\end{array}$ & \multicolumn{4}{|c|}{$\begin{array}{l}\text { Mineral products (87.4); pearls, precious } \\
\text { metals and articles thereof (9.7); Machinery } \\
\text { and appliances (1.3) }\end{array}$} & \multicolumn{4}{|c|}{$\begin{array}{l}\text { Machinery and appliances (32.4); base } \\
\text { metals (11.7); products of the chemical or } \\
\text { allied industries (10.6) }\end{array}$} \\
\hline Botswana & 3,442 & 1,822 & 1,503 & 2,196 & 946 & 273 & 275 & 332 \\
\hline $\begin{array}{l}\text { main commodities } \\
\text { as (\%) of total }\end{array}$ & \multicolumn{4}{|c|}{$\begin{array}{l}\text { Pearls, precious metals and articles } \\
\text { thereof (92.7); base metals, mineral prod- } \\
\text { ucts (5.6); live animals, animal products (1.6 }\end{array}$} & \multicolumn{4}{|c|}{$\begin{array}{l}\text { Pearls, precious metals and articles there- } \\
\text { of (49.1); Machinery and appliances (25.9); } \\
\text { transport equipment (4.7) }\end{array}$} \\
\hline Lesotho & 187 & 247 & 254 & 208 & 15 & 11 & 12 & 12 \\
\hline $\begin{array}{l}\text { main commodities } \\
\text { as (\%) of total }\end{array}$ & \multicolumn{4}{|c|}{$\begin{array}{l}\text { Pearls, precious metals and articles there- } \\
\text { of }(98.3) \text {; vegetable products }(0,9) \text {; textiles } \\
\text { and textile articles }(0.6)\end{array}$} & \multicolumn{4}{|c|}{$\begin{array}{l}\text { Machinery and appliances (32.2); mineral } \\
\text { products (12.8); pulp of wood paper, paper } \\
\text { board; vegetable products (2.4) }\end{array}$} \\
\hline Mozambique & 1,332 & 1,366 & 1,435 & 1,325 & 835 & 894 & 982 & 689 \\
\hline $\begin{array}{l}\text { main commodities } \\
\text { as (\%) of total }\end{array}$ & \multicolumn{4}{|c|}{$\begin{array}{l}\text { Base metals and articles thereof (61.0); } \\
\text { mineral products (16.3); food stuff (13.7) }\end{array}$} & \multicolumn{4}{|c|}{$\begin{array}{l}\text { Machinery and appliances (26.3); products } \\
\text { of the chemical or allied industries (19.6); } \\
\text { transport equipment (10.7) }\end{array}$} \\
\hline Namibia & 941 & 963 & 1,038 & 1,090 & 753 & 538 & 404 & 373 \\
\hline $\begin{array}{l}\text { main commodities } \\
\text { as (\%) of total }\end{array}$ & \multicolumn{4}{|c|}{$\begin{array}{l}\text { Base metals and articles thereof (38.2); Live } \\
\text { animals, animal products ( } 30.3) \text {; pearls, pre- } \\
\text { cious metals and articles thereof (11.3) }\end{array}$} & \multicolumn{4}{|c|}{$\begin{array}{l}\text { Mineral products (33.3); machinery and ap- } \\
\text { pliances (24.2); transport equipment (8.7) }\end{array}$} \\
\hline South Africa & 15,560 & 18,514 & 19,399 & 22,928 & 24,481 & 23,318 & 25,432 & 22,974 \\
\hline $\begin{array}{l}\text { main commodities } \\
\text { as (\%) of total }\end{array}$ & \multicolumn{4}{|c|}{$\begin{array}{l}\text { Pearls, precious metals and articles } \\
\text { thereof (41.6); transport equipment (16.8); } \\
\text { mineral products (8.2) }\end{array}$} & \multicolumn{4}{|c|}{$\begin{array}{l}\text { Machinery and appliances (32.2); transport } \\
\text { equipment (19.8); products of the chemical } \\
\text { or allied industries (13.4) }\end{array}$} \\
\hline Swaziland & 230 & 151 & 139 & 122 & 23 & 29 & 35 & 51 \\
\hline $\begin{array}{l}\text { main commodities } \\
\text { as (\%) of total }\end{array}$ & \multicolumn{4}{|c|}{$\begin{array}{l}\text { Foodstuffs, beverages, tobacco ( } 85.1) ; \\
\text { vegetable products (6.8); products of the } \\
\text { chemical or allied industries (6.0) }\end{array}$} & \multicolumn{4}{|c|}{$\begin{array}{l}\text { Products of the chemical or allied indus- } \\
\text { tries (43.1); miscellaneous manufactured } \\
\text { articles (24.8); Foodstuffs, beverages, } \\
\text { tobacco (7.3) }\end{array}$} \\
\hline
\end{tabular}

Source: own study based on: (European Commission Trade Statistics, 2017).

It is worth emphasising that the EU-28 countries are major trading partners of the SADC. In 2016, the EU received $26 \%$ of the total exports of the region (ahead of China, with a $20.5 \%$ share), whereas supplies from the EU represented nearly $33 \%$ of total 
imports (followed by deliveries from China - almost 18\%). At the same time, the countries concerned only accounted for a limited proportion of extra-EU exports and imports: 1.9\% and 1.6\%, respectively, in 2016 (European Commission Trade Statistics, 2016). The SADC5 countries mostly export mineral products, precious stones and agricultural products such as fruit and sugar to the EU. The EPA countries are strong in exporting diamonds; in South Africa, Botswana, Lesotho and Namibia those constitute a large to dominant share of their exports to the EU [Table 4].

Other products from the region include agricultural products (beef from Botswana, fish from Namibia or sugar from Swaziland), oil from Angola or aluminium from Mozambique. South African exports to the EU are considerably diversified and range from fruit to platinum and from manufactured goods to wine. In its trade with the EU, South Africa faces little competition from the SADC5 countries. It is only in aluminium that SA exports compete with Mozambique. The EU exports a wide range of products to the SADC EPA countries, e.g. vehicles, machinery, electrical equipment, pharmaceuticals and processed foodstuffs.

According to the South Centre's calculations, the SADC EPA countries are only more competitive than the EU on $14 \%$ of total tariff lines ${ }^{18}$. As regards the vast majority of products, the EU is either more competitive (64\%) or the African sub-regions do not currently have local production capacity (22\%).

In the case of $80.5 \%$ of the tariff lines/products on which the SADC EPA countries will eliminate tariffs, local production will be exposed to strong competition from more competitive EU goods. (3,144 out of 3,907 tariff lines). Those are lines subject to liberalisation and where the EU is more competitive than the SADC. Overall, $84.5 \%$ of the total number of tariff lines or products are at risk as a result of the EPA liberalisation (current and future production). The main sectors where regional trade exists and could be disrupted due to the greater competitiveness of the EU are as follows: (South Centre, 2012, p. 4):

- processed oil products,

- chemical products,

- intermediate industrial products,

- final industrial products,

- parts of machines,

- vehicle industry,

- Portland cement,

- processed agricultural products,

- medicines,

- textile and clothing.

\footnotetext{
${ }^{18}$ This is already higher than the other sub-regions: $10 \%$ each for the EAC and ESA EPAs, $6 \%$ for ECOWAS and only $3 \%$ for Central Africa (South Centre, 2012, p. 15).
} 


\section{Conclusions}

The European Union is more interested in entering into the EPA that the countries of the region, therefore it exerted pressure to speed up and finalise EPA negotiations. In addition, the European Union demanded that deepened free trade areas should be created, covering not only goods but also services or investment (full EPAs).

The SADC EPA Group countries constitute no homogeneous bloc, being members of different regional integration communities. Five countries belong to the SACU, a customs union with a single customs area and a common external tariff. The customs area excludes Angola and Mozambique; both countries have their own customs tariffs. Therefore, the IEPA involved the conclusion of new agreements between Mozambique (and possibly Angola at a later time) of the one part and the SACU of the other part. Furthermore, the SACU EPA Group does not include all the member states of the integration community, the other countries participate in EPA negotiations with other regions. Such an approach undermines the fundamental characteristics of customs unions and free trade areas in the region. It is also inconsistent with the objectives of the Cotonou Agreement (Section 3) and the commitments contained in the SADC EPA (Article 1(b) of the SADC EPA ('promote regional integration') and Article 3 ('regional integration') with regard to supporting and strengthening regional integration.

Had the Southern African countries not concluded economic partnership agreements, their customs status in access to the European Union market would be different. In the case of Botswana and Namibia, upper middle-income countries, exports to the EU would be subject to the MFN tariffs, applied to all WTO members. It would mean deteriorated conditions of access to the EU market for certain agricultural products since the MFN tariffs are relatively high. Swaziland, a lower middle-income company, without an EPA would be covered by the GSP. Although the GSP offers a number of tariff preferences, it excludes sugar, a major export product of Swaziland. Therefore, as a matter of fact, the country concerned would also incur costs of having no EPA. Lesotho and Mozambique, the two least developed countries (LDCs) in the region, would still benefit from the EBA arrangement, thus their EU market access conditions would not worsen. The countries would still be beneficiaries of unilateral preferences, i.e. virtually duty-free imports to the EU. There would be no need to lift tariffs on imported EU goods. Trade with South Africa would continue to be regulated by the Trade, Development and Cooperation Agreement (TDCA), providing for only insignificantly worse trade conditions that those contained in the SADC EPA. 


\section{References}

African, Caribbean, and Pacific Group of States, Retrieved 15 November 2017, from http://www. acp.int/content/secretariat-acp.

African Statistical Yearbook 2017, Retrieved 15 November 2017, from www.uneca.org.

Borgatti, L. (2011). Economic integration in Sub-Saharan Africa. In: Jovanowić, M.N., International Handbook on the Economics of Integration, Volume I, Chelthaenham, UK; Northampton, MA, USA: Edward Elgar.

Council Regulation (EC) No 416/2001 of 28 February 2001 amending Regulation (EC) No 2820/98 applying a multiannual scheme of generalised tariff preferences for the period 1 July 1999 to 31 December 2001 so as to extended duty-free access without any quantitative restrictions to products originating in the least developed countries, OJ L 60, 1.03.2001.

Council Regulation (EC) No 1528/2007 of 20 December 2007; Commission Delegated Regulation (EU) No 1016/2014 of 22 July 2014; amending Annex II to Regulation (EU) No 978/2012 of the European Parliament and of the Council applying a scheme of generalised tariff preferences, OJ L 283, 27.9.2014.

Czermińska, M. (2017). European Union's New Generalised System of Preferences-ANew Scenario for Development of Trade with the EU for Beneficiaries of the System? Przedsiębiorczość i Zarządzanie, Volume XVIII, Issue 9, Part I, Wydawnictwo SAN, Łódź-Warszawa, 41-58.

Czermińska, M. (2016). Powszechny system preferencji celnych (GSP) - zmiany warunków dostępu do rynku unijnego dla beneficjentów nowego systemu. Studia i Materiały, Miscellanea Oeconomicae, No. 3/2016, Vol. I, 43-51.

Dinca, T., \& Kennes W. (2007). Africa's Regional Integration Arrangements. History and Challenges. ECDPM, Discussion Paper No. 74, September, 1-34.

European Commission 1996. Green Paper on relations between the European Union and the ACP countries on the eve of the $21^{15 t}$ century, COM (96) 570 final, November.

European Commission 2016a, Economic Partnership Agreement (EPA) between the European Union and the Southern African Development Community (SADC) EPA Group, MEMO/16/3340, Retrieved 15 November 2017 from http://europa.eu/rapid/pressrelease_MEMO-16-3340_en.htm

European Commission 2016b. The Economic Impact of the West Africa - EU Economic Partnership Agreement, p. 16, Retrieved 15 November 2017 from http://trade.ec.europa.eu/doclib/ docs/2016/june/tradoc_154663.pdf

European Commission Trade Statistics, Retrieved 15 November 2017 from http://trade.ec.europa.eu.

Foroutan, F. (1993). Regional Integration in Sub-Saharan Africa: Past Experience and Future Prospects. In: De Melo, J., Panagariya, A. (eds.). New Dimensions in Regional Integration. Cambridge: Cambridge University Press.

Fact sheet on the interim Economic Partnership Agreements, SADC EPA Group. 2011. November. Retrieved 15 November 2017 from trade.ec.europa.eu/doclib/html/142189.htm, p. 2.

Frankowski, P. (2011). Umowy o partnerstwie gospodarczym jako instrument promowania integracji regionalnej w Afryce Subsaharyjskiej. Centrum Europejskie Natolin, Issue 44, 1-172. 
Garlińska-Bielawska, J. (2016). Porozumienie Tripartite Free Trade Area (TFTA) - w kierunku racjonalizacji procesu integracyjnego w Afryce?. Miscellanea Oeconomicae, Studia i Materiały, Faculty of Management and Administration, Jan Kochanowski University in Kielce, No. 3, Vol. I, Kielce, 63-70.

Koné, S. (2010). Economic Partnership Agreement between West Africa and the European Union in the Context of the World Trade Organization (WTO) and the Regional Integration Process. 'Journal of Economic Integration', 25 (1), 105-129.

McCarthy, C.L., Kruger, P. \& Fourie, J. (2007). Benchmarking EPA negotiations between EU and SADC. tralac, Stellenbosch, 1-116.

McCarthy, C.L. (2003). The Southern African Customs Union. FAO UN, February.

Meyn, M. (2003). Das Freihandelsabkommen zwischen Südafrika und der EU und seine Implikationen für die Länder der Southern African Customs Union (SACU). In: Knorr, A., Lemper, A. Sell, A. \& Wohlmuth, K. (eds.). Berichte aus dem Weltwirtschaftlichen Colloquium der Universität Bremen. No. 82, April, 1-42.

Michałowski, T. (2011). Integracja gospodarcza w Afryce na przykładzie Południowoafrykańskiej Unii Celnej. In: Schroeder J. \& Puślecki Ł. (eds.). Gospodarka Międzynarodowa - wyzwania i nowe trendy, Zeszyty Naukowe 179. Poznań, 186-197.

Młodkowski, P. (2007). Pozaeuropejskie unie celne. Historia i funkcjonowanie. Warszawa: Wydawnictwo Naukowe PWN.

Partnership agreement between the members of the African, Caribbean and Pacific Group of States of the one part, and the European Community and its Member States, of the other part, signed in Cotonou on 23 June 2000, OJ L 317, 15.12.2000.

Regulation (EU) No 527/2013 of the European Parliament and of the Council of 21 May 2013 amending Council Regulation (EC) No 1528/2007 as regards the exclusion of a number of countries from the list of regions or states which have concluded negotiations, OJ L 165, 18.06.2013.

Rynarzewski, T., Nawrot, K.A., Zajaczkowski, K. \& Cieślik, K. (2017). Potencjał gospodarczy i możliwości rozwojowe Afryki. Polska Perspektywa, Warszawa: PWE.

South Centre, (2012). The EPAs and risks for Africa: local production and regional trade, Geneva, SC/TDP/AN/EPA/30.

South Centre, (2013). EU-ACP Economic Partnership Agreements: current state of play, Geneva, Analytical Note SC/TDP/AN/EPA/31. 